\title{
Characteristics of Citations in Postgraduate Theses of Sociology and Economics: A Comparative Study
}

Chamani Gunasekera ${ }^{1}$

\begin{abstract}
This study analyses the sources cited in 32 post graduate (Master and $\mathrm{PhD}$ ) theses in sociology and economics at University of Peradeniya submitted between 1996 and 2014. The objectives of this citation analysis were to find out the types of cited documents, the chronological distribution and authorship pattern of cited documents in the fields of sociology and economics, and to compare them. Citations were chosen from the title pages and the lists of references of each dissertation were examined. Data included the year of submission of thesis, source of citations, age of materials cited and types of authorship. Citations to journals were further analyzed to examine their authorship pattern, research collaboration, geographical location and check the applicability to Bradford Law of scattering. Results revealed that both sociology and economics authors cited mostly books, which proved previous studies that found social science disciplines cited books mostly than science disciplines. Citations in both sociology and economics were almost entirely of English language sources. Economics scholars cited latest materials than sociology scholars did. The results indicated that sociology literature is scattered among various subjects than economics. There is no significant difference between the citation behavior of sociology and economics scholars of University of Peradeniya except some differences in chronological distribution and research collaboration. Understanding the citation behavior of sociology and economics scholars will help librarians to formulate pragmatic policies and making decisions on collection development.
\end{abstract}

Key words: Authorship pattern, Citation analysis, References, Graduate theses, Sociology, Economics.

\footnotetext{
${ }^{1}$ Senior Assistant Librarian, Main Library, University of Peradeniya, Sri Lanka. Email: chamanig@yahoo.com
} 


\section{Introduction}

The main purpose of a citation is to confirm the relationship between the citing and cited documents. Citations can be used to assess the relevant sources and authenticate the credibility of an author's statements, and provide a comprehensive reading list of related literature for the researchers (White, 1985). According to Rousseau "referring is mentioning in the proper context and giving an explicit bibliographical statement in a list of references. Older articles are then cited by or will receive citations from the newer ones" (Rousseau, 2008). Citations accredited the existence of related literature (Coleman, 2004) and help to disclose new knowledge among researchers in the same subject field (Leydesdorff, 1998). According to Merton (2000), "citations provide peer recognition that is central scholarly system of science and other fields. Typically, citation shows that a relationship exists between the work of an author and the previous works done in that field."

Citation analysis "refers to references in one text to another text, with information on where that text can be found and it is a useful method for understanding subject relationships, authorship pattern, impact, publication trends and so on" (Chikate \& Patil, 2008, p.1). With citation analysis one can evaluate and interpret citations received by articles, authors, institutions, and other indications of scientific activity (Ravichandra Rao, 1993). Citation analysis is a major area of bibliometric research, which uses various methods of citation analysis to establish relationships between authors and their work.

Citation analysis is an important technique that used by the librarians and information professionals to represent the relationship which exists between the cited and citing document and it involves the process of collection, counting and analysis given in various types of literature. According to Trayambakrao and Sonwane (2012, p.18) citation analysis is "a direct method to analyze the library record to determine the actual sue of the documents. These types of information provide useful idea for acquisition of important material, selection of documents, and the information help librarians as well as information system designers, to plan their products and services." 
Research using citations from graduate theses incline to focus on collection management or collection evaluation issues and graduate citations specially use to examine collection patterns or trend at a particular institution. Another important element in analyzing citation patterns is the insights gained about the social context in which knowledge is created. The operative question is: do researchers use literature differently based on their discipline? Hargens (2000) identified two major scholarly structures, one in which scholars focus on recently published research while tending to ignore foundational work, the other in which scholars focus on early work while tending to ignore recent publications. He reported that the natural sciences tend to fall into the former category, while the humanities and social sciences fall into the latter. Using citation data from a group of theses it is possible to draw some conclusions about scholarly communication at the master's and doctoral levels.

Citation analysis is one of the popular methods used by researchers for identification of core documents and complex relationship between citing and cited documents for a particular scientific community. The purpose of the present study is to investigate the citation pattern of sociology and economics scholars at University of Peradeniya through their postgraduate theses. More specifically, this study addresses the following research questions:

1. Are there differences/similarities between sociology and economics postgraduate researchers' citation patterns by the following: Format? Chronological distribution? Language? Subjects? Geographical distribution?

2. Does the distribution of citations to journals match with Bradford's Law of Scattering?

3. Do authorship pattern and research collaboration of journal citations of postgraduate theses of economics and sociology differ? 
In order to address these questions, the postgraduate theses of sociology and economics submitted from 1996 to 2014 to the main library, University of Peradeniya were selected. Findings of the study could help to identify sources cited and their distribution and citation trends of journal citations.

\section{Objectives of the study}

The main objectives of the study are as follows:

- To understand the citation potential of the Sociology and Economics theses and to know various sources of information used by the Sociology and Economics scholars.

- To find out the chronological distribution and the language of the citations.

- To observe the nature of authorship pattern in the literature of Sociology and Economics, and

- To examine the applicability of Bradford's Law of scattering to the pattern of journals used by the researchers in Sociology and Economics.

\section{Scope of the Study}

The scope of the present study is the master's and doctoral theses and dissertations on sociology and economics submitted to the library, University of Peradeniya between 1996 and 2014. The main purpose of the study is to find out the current citation trends of the graduate dissertations in sociology and economics.

\section{Review of related literature}

The review of literature reveals that a considerable number of studies have been carried out on bibliometrics and citation analysis in various disciplines and most of them were studied on one subject. "The first citation analysis was reported in 1927 by Gross and Gross who studied the cited sources in the bibliographies of articles published in the Journal of the American Chemical Society and used the results to develop a journal subscription policy for a college library in the United States" (Afful \& Janks,2013).

Academic librarians have used various types of citation analysis to study their library collections and the analysis of reference lists of dissertation is 
one approach used to measure library use by graduate students, who are considered as frequent and heavy library users in general. According to Herubel, "dissertations may be invaluable road signs to the literature of a discipline" (Herubel, 1991, p.67). Some examples of this methodology include Sylvia and Lesher's (1995) study of psychology and counseling dissertations, Zafrunnisha (2012) analysed psychology doctoral dissertations, Marinko (1998) examined the dissertations on women's studies and KuyperRushing's (1999) examination of music dissertations. By examining the political science and philosophy dissertations Buchanan and Herubel (1993) investigated serial monograph ratios and they established that the journals were heavily used in these disciplines. Beile, Boote, and Killingsworth (2005) examined the education dissertations to assess the quality of literature used for dissertation writing and knowledge gained from the research. They advised caution in using the results of a citation analysis as a method of collection evaluation.

Zafrunnisha (2012) carried out a study to examine the distribution of authorship pattern, bibliographic format, core journals, country, language, subject wise distribution of journal citations and core periodicals among the doctoral theses of Sociology submitted to Sri Venkateswara University, Tirupati and Osmania University, Hyderabad. He established that the single authored papers were highest contribution in book citations while multi authored papers were highest contribution of the total journal citations. He further confirmed that the sociology researchers in both universities mostly referred books and most of the publications cited were published by developed countries and all the citations were published in English.

Sherriff (2009) conducted a study on citation analysis on history theses submitted between 1998 and 2008 at a public university to address the need for quantitative investigation into Master students' use of information resources. The results revealed that the history research predominant by the monographs and history researchers used older information resources than other disciplines. The author has concluded that journal usage was significantly lower than in other disciplines and there was a high degree of citation dispersal across journal titles. The study further established that the 
cited monographs were predominantly history-focused, whereas cited journals had a high degree of interdisciplinary while foreign-language resources may be important to individual theses but are little-used overall.

Nasir and Kumar (2011) conducted a citation analysis in economics doctoral dissertations submitted between 1990-2010 to the Aligarh Muslim University, India to examine the authorship patterns, bibliographic format, and language, country of origin, age and ranking of journals by citation frequency. They established that books were the most dominant format in which information was used in economics. The dominant language of the literature cited was English and the single authorship prevails in the citations. These results confirmed by later study conducted by Trayambarko and Sonwane (2012) at the University of Dr. Babasaheb Ambekar Marathwade, India.

Harwade and Dankhade (2002) carried out a study to examine the citation pattern in economic theses submitted to Nagpur University, India. The Study established that $43 \%$ of citations were books followed by $33 \%$ journals and $15 \% \mathrm{PhD}$ theses. The study further confirmed that the single authored papers were the highest in number and half -life period for journals was 22 years. Ramesh (2002) analysed $381 \mathrm{PhD}$ dissertations submitted by research scholars to different Indian Universities during the fifty years and Bandopadhyay (2003) analysed 11,221 citations cited in 92 doctoral theses concerning to five different disciplines of science, namely, Mathematics, physics, Mechanical Engineering, Political Science and Philosophy. Chandra Kumar and Sritharan (2003) also investigated to ascertain the referencing pattern of Sanskrit doctoral dissertations submitted to University of Madras from the period 1993-2000.

Similarly, Singh and Bebi (2013) conducted a study over 5700 citations from $25 \mathrm{PhD}$ theses on sociology submitted in the discipline of sociology of the University of Delhi during 1995-2010. The study found that the books were the most heavily used format and the single authorship appeared most in the citations. The country-wise scattering of citations revealed that nearly half of the citations were from India and it was followed by USA and UK. 
However, Meho said that "not everybody think citation analysis is the best way to judge the validity of a scientific claim. Critics point to basic citing errors such as homographs, i.e. failing to separate citations to two unrelated scientists who happen to share the same last name and first initial. Cronyism, whereby friends or colleagues reciprocally cite each other to mutually build their citation counts, is another drawback. Other problems include people deliberately citing themselves or journals they are involved with; ceremonial citations, in which an author cites an authority in the field without ever having consulted the relevant work it; and negative citations pointing out incorrect results" (Meho, 2007, p.2-3).

\section{Research Methods}

The study used descriptive research design. Master's and doctoral thesis in the fields of Sociology and Economics submitted to the Main library, University of Peradeniya during the period of 1996 to 2014 were examined. Purposive sampling technique was used in the study. Citations were extracted from the title pages and reference lists of each of the dissertations were examined. Chosen data included the year of submission of thesis, source of citations, age of materials cited, language of cited materials, types of authorship and types of journals.

The information relating to each citation i.e., number of authors, bibliographic format, name of the journal, subject and language were concerned. If the citations were from a journal, the information regarding the country and the subject of the journal were obtained from the "Guide to Retrospective Periodical Holdings in the Main Library University of Peradeniya" and recorded on the catalogue cards. The data is fed into the computer using MS-Excel software and the Statistical Package for Social Sciences (SPSS) for analysis.

Data obtained from twelve (12) master theses and two (02) doctoral dissertations on sociology and 16 masters and 2 doctoral dissertations on economics were examined during the latter half of February 2015. The data extracted were analysed using descriptive statistics which includes frequency and percentage presented in the tables. 
The citation formats were classified mostly in accordance with the categories established by Musser and Conkling (1996) with some elaboration.

\section{Results and Discussion}

Three thousand five hundred and seventy eight (3578) citations were analyzed to ascertain the authorship patterns along with calculation of collaboration coefficient, types of literature, languages, subjects of journals, time span, and geographical distribution.

\section{Distribution of Citations}

Sociology theses contained 1603 citations and average number of citations was 115 with a range from 53 to 233 whereas economics theses contained 1975 citations (Average $=110$ ) with a range from 22 to 227 citations. A total of 28 master's theses and 04 doctoral dissertations which produced thirty two in all were gathered and 3578 citations were generated and the mean number of citation was 112 with a range from 22 to 233 citations.

\section{Citation potential}

Frequency distribution of citations potentials is given in the Table 1. It is clear from the Table 1 that out of 32 theses, the highest number of citations range i.e. 201-250 had only in three theses when minimum citation range from 1-50 had in two theses. Eleven theses contained citations from 51-100 followed by 10 theses having citations range from 101-150. These results revealed that the variations in citations are in sociology and economics theses.

Table 1: Frequency of citations in the theses

\begin{tabular}{|c|c|c|c|c|}
\hline $\mathbf{S} / \mathbf{N}$ & $\begin{array}{l}\text { No. of } \\
\text { citations }\end{array}$ & $\begin{array}{l}\text { Sociology } \\
\text { theses } \\
\text { No. }(\%)\end{array}$ & $\begin{array}{l}\text { Economics } \\
\text { theses } \\
\text { No. }(\%)\end{array}$ & $\begin{array}{l}\text { All theses } \\
\text { No. (\%) }\end{array}$ \\
\hline 1 & $1-50$ & $0(0 \%)$ & $2(11 \%)$ & $2(6.2 \%)$ \\
\hline 2 & $51-100$ & $5(36 \%)$ & $6(33 \%)$ & $11(34.5 \%)$ \\
\hline 3 & $101-150$ & $6(43 \%)$ & $4(22 \%)$ & $10(31.3 \%)$ \\
\hline 4 & $151-200$ & $1(7 \%)$ & $5(28 \%)$ & $6(18.6 \%)$ \\
\hline \multirow[t]{2}{*}{5} & $201-250$ & $2(14 \%)$ & $1(6 \%)$ & $3(9.4 \%)$ \\
\hline & Total & $14(100 \%)$ & $18(100 \%)$ & $32(100 \%)$ \\
\hline
\end{tabular}




\section{The Sources Cited and Their Distribution}

Studying of distribution of the sources cited in theses is one of the objectives of this study. Therefore the results obtained from the analysis in relation to the format of cited materials were presented in table 2 below.

Table 2: Citation according to types of information materials

\begin{tabular}{|l|l|l|l|}
\hline \multicolumn{1}{|c|}{ Material type } & $\begin{array}{l}\text { Sociology theses } \\
\text { No. (\%) }\end{array}$ & $\begin{array}{l}\text { Economics theses } \\
\text { No. (\%) }\end{array}$ & \multicolumn{1}{|c|}{$\begin{array}{c}\text { All theses } \\
\text { No. (\%) }\end{array}$} \\
\hline Journals & $356(22.2 \%)$ & $507(25.7 \%)$ & $863(24.1 \%)$ \\
\hline Monographs & $926(57.8 \%)$ & $962(48.7 \%)$ & $1888(52.8 \%)$ \\
\hline Conference proceedings & $52(3.2 \%)$ & $88(4.5 \%)$ & $140(3.9 \%)$ \\
\hline Reports & $118(7.4 \%)$ & $179(9.1 \%)$ & $297(8.3 \%)$ \\
\hline Theses \& dissertations & $29(1.8 \%)$ & $7(0.4 \%)$ & $36(1 \%)$ \\
\hline Web resources & $69(4.3 \%)$ & $69(3.5 \%)$ & $138(3.8 \%)$ \\
\hline $\begin{array}{l}\text { Government } \\
\text { publications }\end{array}$ & $23(1.4 \%)$ & $95(4.8 \%)$ & $118(3.3 \%)$ \\
\hline Miscellaneous & $30(1.9 \%)$ & $68(3.3 \%)$ & $98(2.8 \%)$ \\
\hline Total & $1603(100 \%)$ & $1975(100 \%)$ & $3578(100 \%)$ \\
\hline
\end{tabular}

As shown in the Table 2, the percentage of citations to monographs was higher in sociology theses $(58 \%)$ than that of economics theses (48\%). When compared to other formats there was not much of difference among them other than government publications. According to the findings, more than $70 \%$ of the citations in the reference list of both sociology and economics theses are from books and journals and the rest of the citations are from reports, web sources, conference proceedings and government publications.

The types of sources cited differ according to the subject fields. According the literature sociology is the discipline where books constitute the most cited sources and it is proved in the present study whereas $57.8 \%$ of citations were monographs. Most of the existing citations analysis in humanities theses examined whether scholars cited more books or journals. Most of them found a higher percentage of citations to monographs. However, inconsistent counting methods make these numbers difficult to compare, since some other studies counted duplicate citations more than once, or included government publications as books, while this study did not. 
Anyway the findings confirmed the results of other studies (Zafrunnisha, 2012; Trayambakrao \& Sonwane, 2012; Singh \& Bebi, 2013).

\section{Difference between Print citations and Electronic citations}

The material classification above referred only to format of citations used. Thus an e-journal and a print journal would be classified together as a journal. Further analysis was conducted on the data and the Table 3 indicates that the majority of the cited sources were in print form.

Table 3: Distribution of citations between print and electronic formats

\begin{tabular}{|l|l|l|c|}
\hline Format & $\begin{array}{l}\text { Sociology } \\
\text { theses } \\
\text { No. }(\%)\end{array}$ & $\begin{array}{l}\text { Economics } \\
\text { theses } \\
\text { No. }(\%)\end{array}$ & Total theses \\
No. (\%) $)$
\end{tabular}

As shown in the above table $94 \%$ of sources cited in sociology theses was in print form whereas $95 \%$ of the citations cited in economics theses. There are some possible reasons for this, they might have assumed that citing printed source would win them more academic and/or they may be not aware about how to cite electronic version or perhaps it was simply easier to cite in the printed format.

\section{Chronological distribution of citations}

The duration of the whole period was divided into 12 sections as shown in the Table 4.

The highest citations were recorded in the period from 1951-1960 in the field of sociology whereas the period from 1991-2000 was recorded with highest number of citations $(n=765)$ in the field of economics that proves economics scholars use substantially new materials with compared to sociology scholars. It is evident from above table that $91 \%$ of citations in the sociology theses were recorded in the period from 1951-2000 whereas $96 \%$ of citations in the economics theses were recorded in the period from 1971-2010 which denotes that economics scholars used more recent resources than sociologists. 
Table 4: Distribution of citations by selected time period

\begin{tabular}{|l|l|l|l|}
\hline Time period & $\begin{array}{l}\text { Sociology theses } \\
\text { No. }(\mathbf{\%})\end{array}$ & $\begin{array}{l}\text { Economics theses } \\
\text { No. } \mathbf{( \% )}\end{array}$ & $\begin{array}{l}\text { Total theses } \\
\text { No. }(\mathbf{\%})\end{array}$ \\
\hline Before 1900 & $5(0.3 \%)$ & $3(0.2 \%)$ & $8(0.2 \%)$ \\
\hline $1901-1910$ & $1(0.1 \%)$ & $1(0.1 \%)$ & $2(0.05 \%)$ \\
\hline $1911-1920$ & $5(0.3 \%)$ & $4(0.2 \%)$ & $9(0.25 \%)$ \\
\hline $1921-1930$ & $9(0.6 \%)$ & $3(0.2 \%)$ & $12(0.33 \%)$ \\
\hline $1931-1940$ & $22(1.4 \%)$ & $8(0.4 \%)$ & $30(0.84 \%)$ \\
\hline $1941-1950$ & $53(3.3 \%)$ & $14(0.7 \%)$ & $67(1.89 \%)$ \\
\hline $1951-1960$ & $458(28.6 \%)$ & $55(2.8 \%)$ & $513(14.3 \%)$ \\
\hline $1961-1970$ & $209(13 \%)$ & $88(4.5 \%)$ & $297(8.31 \%)$ \\
\hline $1971-1980$ & $282(17.6 \%)$ & $156(7.9 \%)$ & $438(12.2 \%)$ \\
\hline $1981-1990$ & $284(17.7 \%)$ & $320(16.2 \%)$ & $604(16.9 \%)$ \\
\hline $1991-2000$ & $223(13.9 \%)$ & $765(38.7 \%)$ & $988(27.6 \%)$ \\
\hline $2001-2010$ & $22(1.4 \%)$ & $558(28.3 \%)$ & $580(16.2 \%)$ \\
\hline Unknown & $30(1.8 \%)$ & 0 & $30(0.84 \%)$ \\
\hline Total & $1603(100 \%)$ & $1975(100 \%)$ & $3578(100 \%)$ \\
\hline
\end{tabular}

\section{Distribution of citations in terms of Language}

This study also examines the language of the publications cited in order to find the preferences of sociology and economics researchers on local or foreign literature. The total citations found from sociology and economics theses were distributed among 3 different languages as shown in the Table 5.

Table 5: Distribution of cited literature by language

\begin{tabular}{|l|l|l|l|}
\hline Language & $\begin{array}{l}\text { Sociology theses } \\
\text { No. (\%) }\end{array}$ & $\begin{array}{l}\text { Economics theses } \\
\text { No. }(\%)\end{array}$ & $\begin{array}{l}\text { Total theses } \\
\text { No. }(\%)\end{array}$ \\
\hline English & $1404(87.6 \%)$ & $1751(88.7 \%)$ & $3155(88.2 \%)$ \\
\hline Sinhalese & $194(12.1 \%)$ & $224(11.3 \%)$ & $418(11.7 \%)$ \\
\hline other & $5(0.3 \%)$ & 0 & $5(0.1 \%)$ \\
\hline Total & $1603(100 \%)$ & $1975(100 \%)$ & $3578(100 \%)$ \\
\hline
\end{tabular}

Table 5 revealed that the language of citations is predominantly by English while constituting nearly $88 \%$ of citations appeared in both sociology and economics theses. 


\section{Analysis of journal citations}

Journals are vital resources for disseminating results of new knowledge gained from the research in any subject field. Therefore the journals were further analysed to find out trends of journal literature.

\section{Authorship pattern of journal citations}

The characteristics of subject literature consist of not only the basic publishing patterns but the authorship pattern too. Authorship has been analyzed to determine the percentage of single and multiple authors are given in Table 6.

Table 6: Authorship pattern of journals cited

\begin{tabular}{|l|l|l|l|}
\hline $\begin{array}{l}\text { Number of } \\
\text { Authors }\end{array}$ & $\begin{array}{l}\text { Sociology theses } \\
\text { No. (\%) }\end{array}$ & $\begin{array}{l}\text { Economics theses } \\
\text { No. (\%) }\end{array}$ & $\begin{array}{l}\text { Total theses } \\
\text { No. (\%) }\end{array}$ \\
\hline 1 & $294(81.9 \%)$ & $320(63.6 \%)$ & $614(71.2 \%)$ \\
\hline 2 & $46(12.8 \%)$ & $165(32.8 \%)$ & $211(24.5 \%)$ \\
\hline 3 & $13(3.6 \%)$ & $12(2.4 \%)$ & $25(2.9 \%)$ \\
\hline 4 & $05(1.4 \%)$ & $05(1 \%)$ & $10(1.2 \%)$ \\
\hline 5 & $01(0.3 \%)$ & $01(0.2 \%)$ & $02(0.2 \%)$ \\
\hline$>5$ & 0 & 0 & 0 \\
\hline Total & $359(100 \%)$ & $503(100 \%)$ & $862(100 \%)$ \\
\hline
\end{tabular}

As explicit in the above table the single authorship is most prominent. Nearly $82 \%$ of citations are single authored in the field of sociology whereas only $63.6 \%$ of citations are single authored in the field of economics. More than $32 \%$ of the citations had two authors in the field of economics but only $12.8 \%$ citations having two authors in the field of sociology. Similar results could be found in both fields with regard the citations having more than two authors i.e. three, four and five.

\section{Research collaboration}

Collaborative research is the effort of intellectual sharing of two or more persons. The extent of collaboration can be measured with the help of multi authored papers using the formula given by Subramanyam (1983).

$C=\frac{N M}{N M+N S}$ 
Where, $C$ - degree of collaboration in a discipline

$N M$ - No. of multi authored papers

$N S$ - No. of single authored papers

Table 7: Degree of collaboration in research literature

\begin{tabular}{|c|c|c|c|}
\hline Description & Sociology theses & Economics theses & All theses \\
\hline $\begin{array}{l}\text { No. of multi } \\
\text { authored papers } \\
\text { (NM) }\end{array}$ & 65 & 183 & 248 \\
\hline $\begin{array}{l}\text { No. of multi } \\
\text { authored papers } \\
(\mathrm{NM})+\text { No. of } \\
\text { single authored } \\
\text { papers (NS) }\end{array}$ & $\begin{array}{l}359 \\
(65+359)\end{array}$ & $\begin{array}{l}503 \\
(183+320)\end{array}$ & $\begin{array}{l}862 \\
(359+503)\end{array}$ \\
\hline Collaboration & 0.18 & 0.36 & 0.29 \\
\hline
\end{tabular}

The degree of collaboration in the field of sociology is 0.18 whereas degree of collaboration in the field of economics is 0.36 which proves less collaborative work in sociology than economics scholars.

\section{Application of Bradford Law}

The journal citations in sociology and economics theses were placed into three zones according to Bradford's Law of journal scattering (Bradford, 1948). The number of journal citations was divided by 3 to determine how many citations should be included in each zone. Table 8 gives the number and percentages of journal titles along with those of citations for each zone.

The first zone went to the most heavily cited 12 journal titles in sociology theses and 8 journal titles in economics theses whereas the second zone went to 21 and 31 moderately cited journals in sociology and economics theses respectively. The third zone went with 106 and 119 infrequently cited journal titles in sociology and economics theses respectively.

According to Bradford, the relationship between the zones is 1: a: a2.When the data has been applied to test Bradford's Law of scattering it is found that the journal literature cited by both sociology and economics scholars do not 
fit the Bradford's Law of scattering. The ratio of the number of journal titles in the three zones in sociology is 12:21:106 and economics is 08: $31: 119$ and the number of journal titles in each zone is not increasing geometrically. Hence, it is established that the journal usage pattern in the disciplines of sociology and economics does not satisfy the verbal formulation of Bradford's Law of scattering.

Table 8: Journals and journal citations in each Bradford zone

\begin{tabular}{|l|l|l|l|l|l|l|}
\hline \multirow{2}{*}{ Zone } & \multicolumn{2}{|l|}{ Sociology theses } & \multicolumn{2}{l|}{ Economics theses } & \multicolumn{2}{|c|}{ Total theses } \\
\cline { 2 - 7 } & $\begin{array}{l}\text { No. of } \\
\text { journals } \\
\mathbf{\&} \%\end{array}$ & $\begin{array}{l}\text { No. of } \\
\text { citations } \\
\mathbf{\&} \%\end{array}$ & $\begin{array}{l}\text { No. of } \\
\text { journals } \\
\mathbf{\&} \%\end{array}$ & $\begin{array}{l}\text { No. of } \\
\text { citations } \\
\mathbf{\&} \%\end{array}$ & $\begin{array}{l}\text { No. of } \\
\text { journals } \\
\mathbf{\&} \%\end{array}$ & $\begin{array}{l}\text { No. of } \\
\text { citations } \\
\boldsymbol{\&} \%\end{array}$ \\
\hline 1 & 12 & 127 & 8 & 160 & 20 & 287 \\
& $(8.6 \%)$ & $(35.7 \%)$ & $(4.4 \%)$ & $(31.8 \%)$ & $(6.75 \%)$ & $(33.3 \%)$ \\
\hline 2 & 21 & 88 & 31 & 175 & 52 & 263 \\
& $(15.1 \%)$ & $(24.7 \%)$ & $(19.6 \%)$ & $(34.8 \%)$ & $(17.5 \%)$ & $(30.5 \%)$ \\
\hline 3 & 106 & 144 & 119 & 168 & 225 & 312 \\
& $(76.3 \%)$ & $(39.6 \%)$ & $(76 \%)$ & $(33.4 \%)$ & $(75.75 \%)$ & $(36.2 \%)$ \\
\hline Total & 139 & 359 & 158 & 503 & 297 & 862 \\
& $(100 \%)$ & $(100 \%)$ & $(100 \%)$ & $(100 \%)$ & $(100 \%)$ & $(100 \%)$ \\
\hline
\end{tabular}

\section{Subject wise distribution of Journals}

The distribution of journal citations appended in the sociology theses according to the subjects is shown in the Table 9.

Results of the table 9 revealed that the $26 \%$ of journal citations were on sociology followed by $21 \%$ were on economics in the field of sociology but in contrast $89 \%$ of journal citations were on economics in the economics theses. It is evident from above table that the sociology literature is scattered among various subjects than economics.

\section{Geographic distribution of the journal citations}

Geographical analysis of citations provides information about the countries active in a subject field and their relative contribution. Table 10 shows the journals cited in the postgraduate theses accordingly their geographical locations under the category of local or foreign. 
Table 9: Subject wise distribution of journals cited

\begin{tabular}{|l|l|l|}
\hline Subject & $\begin{array}{l}\text { Sociology } \\
\text { Frequency \& \% }\end{array}$ & $\begin{array}{l}\text { Economics } \\
\text { Frequency \& \% }\end{array}$ \\
\hline Sociology & $93(25.9 \%)$ & 0 \\
\hline Economics & $75(20.9 \%)$ & $447(88.9 \%)$ \\
\hline Anthropology & $12(3.3 \%)$ & 0 \\
\hline Statistics & 0 & $2(0.4 \%)$ \\
\hline Social work & $1(0.3 \%)$ & 0 \\
\hline Psychology & $1(0.3 \%)$ & 0 \\
\hline Public administration & $1(0.3 \%)$ & $12(2.4 \%)$ \\
\hline Geography & $5(1.4 \%)$ & $3(0.6 \%)$ \\
\hline Medicine & $18(5 \%)$ & 0 \\
\hline Political science & $13(3.6 \%)$ & $1(0.2 \%)$ \\
\hline Education & $1(0.3 \%)$ & $11(2.2 \%)$ \\
\hline Science & $4(1.1 \%)$ & 0 \\
\hline $\begin{array}{l}\text { Community } \\
\text { development }\end{array}$ & $13(3.6 \%)$ & 0 \\
\hline Youth \& adolescent & $1(0.3 \%)$ & 0 \\
\hline Family Planning & $4(1.1 \%)$ & 0 \\
\hline Humanities & $6(1.7 \%)$ & 0 \\
\hline Women Studies & $8(2.2 \%)$ & 0 \\
\hline law & $2(0.6 \%)$ & 0 \\
\hline History & $21(5.8 \%)$ & $6(1.2 \%)$ \\
\hline Population studies & $13(3.6 \%)$ & 0 \\
\hline Agriculture & $4(1.1 \%)$ & $1(0.2 \%)$ \\
\hline $\begin{array}{l}\text { International } \\
\text { development }\end{array}$ & $6(1.7 \%)$ & 0 \\
\hline Other & $20(5.6 \%)$ & $20(3.9 \%)$ \\
\hline Unidentified & $37(10.3 \%)$ & 0 \\
\hline Total & $359(100 \%)$ & $503(100 \%)$ \\
\hline & & \\
\hline
\end{tabular}

Table 10: Geographical location of journals cited

\begin{tabular}{|l|l|l|l|}
\hline $\begin{array}{l}\text { Geographical } \\
\text { location }\end{array}$ & $\begin{array}{l}\text { Sociology theses } \\
\text { Frequency \& } \\
\text { \% }\end{array}$ & $\begin{array}{l}\text { Economics theses } \\
\text { Frequency \& \% }\end{array}$ & $\begin{array}{l}\text { Total theses } \\
\text { Frequency \& \% }\end{array}$ \\
\hline Foreign & $261(72.7 \%)$ & $399(79.3 \%)$ & $660(76.6 \%)$ \\
\hline Local & $98(27.3 \%)$ & $104(20.7 \%)$ & $202(23.4 \%)$ \\
\hline Total & $359(100 \%)$ & $503(100 \%)$ & $862(100 \%)$ \\
\hline
\end{tabular}


It reveals that the foreign journals predominate in both sociology $(73 \%)$ and economics $(79 \%)$ theses and the results prove that these scholars mostly depend on foreign journals than locals ones.

\section{Conclusion}

Postgraduate theses of both sociology and economics at University of Peradeniya heavily cited books than journals and the English language is predominated in two fields. When anlaysed the chorological distribution of the theses, the field of economics cited more recently published materials than in the field of sociology and both scholars prefer to use printed materials than electronics. The single authorship appeared most in the citations in the present study and the results proved that less collaborative work in sociology than economics scholars. The results further established that the journal usage pattern in the disciplines of sociology and economics does not satisfy the verbal formulation of Bradford's Law of scattering.

The study led to the general conclusion that there is not much difference between the citation behavior of sociology and economics scholars in the University of Peradeniya except some differences in chronological distribution and research collaboration. Further study of citation behavior in other social sciences and humanities disciplines would be useful to understand the citation behavior of other disciplines as well. Understanding the citation behavior of sociology and economics scholars will help librarians to formulate various policies and making decisions on collection development.

\section{References}

Afful, J.B.A \& Janks, H. (2013). The politics of citation: an analysis of doctoral theses across disciplines. Critical approaches to discourse analysis across disciplines, 6 (2), 193-210. Retrieved from http://www.lancaster.ac.uk/fass/journals/cadaad/wpcontent/uploads/2015/ 01/ Volume-6_Afful-Janks.pdf (03-03-2015).

Bandopadhyay, A.K. (2003). Bibliometrics with the help of computers. Burdwan, University of Burdwan.

Beile, P.M., Boote, D.N. \& Killingsworth, E.K. (2005). Exploring the use of doctoral dissertations in building research collection: A citation 
analysis of Education dissertation. Journal of Academic Librarianship, 30(5), 347-353.

Bradford, S.C. (1948). Documentation, Crosby Lackwood: London.

Buchanan, A.L. \& Herubel, John-Pierre V.M. (1993). Comparing material used in philosophy and political science dissertations: a technical note. Behavioral and Social Science Librarian, 12, 63-70.

Chandra, K. \& Srithran, T. (2003). Referencing pattern among the Sanskrit researchers: a citation study, ILA Bulletin, 39, 27-32.

Chikate, R.V. \& Patil, S.K. (2008). Citation analysis of theses in library and information science submitted to University of Pune: A pilot study, Library Philosophy and Practice. Retrieved from http:// nllib.unl.edu/LPP/chikate-patil.htm (23-03-2015).

Coleman, A. (2005). Instruments of Cognition: use of citations and Web links in online teaching materials. Journal of the American Society for Information Science and Technology, 56 (4), 382 - 392.

Hargens, L.L. (2000). Using the literature: reference network, reference context and the social structure of scholarship. American Sociology Review, 65 (6), 846-847.

Harwade, M.A. \& Dankhade, S.S.K. (2002). Citation analysis of doctoral research in Economics, ILA Bulletin, 38, 36-45.

Herubel, John-Pierre V.M. (1991) Philosophy dissertation bibliographies and citations in serials evaluation. The Serials Librarian, 20, 65-73.

Kuyper-Rushing, L. (1999) Identifying uniform core journals titles for music libraries: a dissertations citation study, College \& Research Libraries, 60 (2), 153-163.

Leydesdorff, L. (1998). Theories of citations. Scientometrics, 43(1), 5-25.

Meho, L. I. (2007). The rise and rise of citation analysis, Physics World. 20(1). Retrieved from http://www.sis.indiana.edu/faculty/meho/ PhysicsWorld.pdf (28-02-2015).

Merton, R. K. (2000). On the Garfield input to the sociology of science: A retrospective collage. In Cronin, B. \& Atkins, H. (Eds.). The Web of knowledge: A Festschrift in honor of Eugene Garfield (pp. 435-448). Medford, NJ: Information Today.

Musser, L.R. \& Conkling, T.W. (1996). Characteristics of engineering citations. Science and Technology Libraries, 15(4), 41-49.

Nasir, J. and Kumar, D. (2011) Citation analysis of doctoral dissertations submitted between 1990 and 2010 at the Department of Economics, Aligarh Muslim University, Aligarh, India. Chinese Librarianship: 
An International Electronic Journal, 32. Retrieved from http://www.icic.us/cliej/cl32NK.pdf (20-02-2015).

Ramesh, L.S.R.C. (2002). Fifty years of Library and Information Science research in India: a bibliometric study. Indian Journal of Information Library and Society. 15, 45-48.

Ravichandra Rao, I. K. (1973). Obsolescence and utility factors of periodical publications: A case study. Library Science with a Slant to Documentation, 10(3), 297-307.

Rousseau, R. (2008). Social information systems: Emerging technology and applications for searching the web effectively. Information Science Reference, 13, 252 -267.

Sherriff, G. (2009). Information use in History research: A citation analysis of master's level thesis at Southern Connecticut State University. Retrieved from http://gsherriffmls.com/680 paper.pdf (02-07-2015).

Singh, K.P. \& Bebi, K.P. (2013). Citation Analysis of PhD Theses in Sociology Submitted to University of Delhi during 1995-2010. DESIDOC Journal of Library \& Information Technology, 33(6), 489493.

Subramanyam, K. (1983). Bibliometric studies of research collaboration: a review. Journal of Information Science, 6(3), 23-26.

Sylvia, M. \& Lesher, M.L. (1995). What journal do psychology graduate students need? a citation analysis of thesis references. College \& Research Libraries 56(4): 313-318.

Trayambakrao, K.D. and Sonwane, S.S. (2012). Citation analysis of PhD theses of Economics submitted to Dr. Basaheb Ambedhkar Marathwade University, Electronic International Interdisciplinary Research Journal (EIIRJ). Retrieved from http://eiirj1.weebly.com/uploads/1/0/8/0/10800505 /2kt.pdf (23-072015).

Zafrunnisha, N (.2012). Citation analysis of PhD theses in psychology of selected universities of Andhra Pradesh, India. Library Philosophy and Practice (e- Journal), Retrieved March 05, 2015, from http://digitalcommons.unl.edu/libphilprac/

Zafrunnisha, N. (2012). Citations in the Sociology doctoral dissertations: A quantitative analysis. International Journal of Information Dissemination and Technology, 2(3), 212-218. 